\title{
Hard cash, easy credit, fictitious capital: Critical reflections on money as a fetishised social relation
}

\author{
Bob Jessop \\ Lancaster University, UK
}

\begin{abstract}
This article explores some aspects of money as a social relation. Starting from Polanyi, it explores the nature of money as a non-commodity, real commodity, quasi-commodity, and fictitious commodity. The development of credit-debt relations is important in the last respect, especially in market economies where money in the form of coins and banknotes plays a minor role. This argument is developed through some key concepts from Marx concerning money as a fetishised and contradictory social relation, especially his crucial distinction, absent from Polanyi, between money as money and money as capital, each with its own form of fetishism. Attention then turns to Minsky's work on Ponzi finance and what one might describe as cycles of the expansion of easy credit and the scramble for hard cash. This analysis is re-contextualised in terms of financialisation and finance-dominated accumulation, which promote securitisation and the autonomisation of credit money, interest-bearing capital. The article ends with brief reflections on the role of easy credit and hard cash in the surprising survival of neo-liberal economic and political regimes since the North Atlantic Financial Crisis became evident.
\end{abstract}

\section{Keywords}

Marxism, money, credit, fictitious capital, commodity, debt

\section{Introduction}

Although the title of this first issue of Finance and Society is 'hard cash', 'hard cash' (in the sense of circulating coins and banknotes) has long been insignificant in the overall operation of modern capitalism. Money in the form of credit matters far more and relaxes the need for hard cash. However, major financial crises can be caused by easy credit and this, in turn, leads to a scramble for hard cash - or at least more credible forms of credit. When public credit is used to rescue too-big-to-fail private sector debtors, this can lead to austerity politics that imposes a politics of hard cash in hard times. These themes organise the present contribution, 
which focuses on the nature of money, credit, and debt relations, and their role in capital accumulation and public finance. The main argument is that money is not a thing but a fetishised social relation with the potential to generate economic, financial, and fiscal crises. More precisely, it is a not a single social relation but a complex and contradictory ensemble of social relations. It can circulate as a non-commodity, a fictitious commodity, a quasicommodity, and a real commodity; and, in these (and other) regards, it has diverse forms and functions. Of special significance are the tensions between money as money and money as capital and, in regard to public finance, between private credit and state fiat money. Thus an adequate account of money should consider four interrelated moments of the money, credit, and capital forms: (1) the functions of money; (2) the hierarchy of money forms; (3) the tension between 'national currency' and world money, and its reflection in a changing currency pyramid; and (4) the role of credit-debt relations in generating and/or mediating crisistendencies in capitalist social formations. While these complex and contradictory features underpin the abstract possibility of economic crises in the capitalist mode of production, their actual forms of appearance and consequences depend on the particular assemblage of social relations in a given capitalist formation. To address these issues I first draw on Karl Polanyi, then turn to Karl Marx, note some lessons from Hyman Minsky about financial instability, and finally relate these reflections to the North Atlantic Financial Crisis (NAFC).

\section{Fictitious commodities}

Karl Polanyi (1982: 33) defined the economy in its substantive sense as "an instituted process of interaction between man and his environment, which results in a continuous supply of wantsatisfying material means". It need not involve (and for millennia did not involve) a significant economic role for money. ${ }^{1}$ Polanyi was less concerned in how production was organised than in how products were distributed. He identified four main principles: (1) householding based on autarkic production to satisfy the needs of a largely self-sufficient unit such as a family, settlement, monastery, or manor; (2) reciprocity among similarly patterned or organised groupings (e.g., segmentary kinship groups); (3) redistribution through an allocative centre linked to a political regime; and (4) exchange mediated through price-making markets in a disembedded and potentially self-regulating economy (Polanyi, 1957: 47-53; 1977: 34-47; 1982: 35). On this basis, he noted that economic activities in pre-capitalist formations were not undertaken mainly for 'economic' motives, i.e., for monetary gain or for fear of going hungry for lack of sufficiently remunerative employment (Polanyi, 1977: 51-2). Rather, they were embedded in social activities and institutions for which other motives and/or social purposes were primary. With the rise of market economies, however, economic activities have become increasingly dominated by profit-oriented, market-mediated activities.

Polanyi criticised the 'economistic fallacy' that assimilates the properties and dynamics of non-capitalist economies to those of market economies. A similar fallacy occurs with the assimilation of fictitious commodities in market economies to real commodities (cf. Christophers, 2011). Indeed, one of Polanyi's most important contributions to critical social science was his insistence that land, labour, and money were not real commodities. He argued that land is the natural environment of human beings, labour is simply human activity, and money is just a unit of account. Even where they acquire a price, they are either not produced at all (e.g., land is a free gift of nature) or, if their production requires human activity (e.g., baking bread, making tally sticks), this activity need not be motivated by the hope of pecuniary gain. Matters change with the rise of the (capitalist) market economy. This not only relies on 
the principle of exchange but also generalises exchange relations to all elements of industry, including land, labour, and money (Polanyi, 1977: 71). While Polanyi (1957: 72) acknowledges that all three elements are "absolutely vital parts" of the market economy, he adds that "[t]he postulate that they are produced for sale is emphatically untrue". They are fictitious commodities. Yet "it is with the help of this fiction that the actual markets for labour, land and money are organized" (Polanyi, 1957: 72). It also legitimates the idea that each factor of production is entitled to its own share of the total income and/or wealth of society. So "there was a market price for the use of labor power, called wages, and a market price for the use of land, called rent" (Polanyi, 1977: 10). For money, Polanyi argues, the price is the payment of interest. On this point, matters are, as we shall see, a bit more complex than he suggests. But we can certainly agree that most forms of money have a price (or prices) expressed in the mystified, mystifying forms of interest rates and exchange rates, and of capitalised discounted future earnings.

Marx anticipated this analysis in his 'trinity formula', which signifies how surplus-value is distributed as revenue among three reified factors of production (capital, land, labour). Further, in contrast to Polanyi, who stayed at the level of surface appearances of "market prices' for fictitious commodities, Marx distinguished profit-generating capital (which obtained profits of enterprise) from interest-bearing capital (which received interest) and, more importantly, entered the 'secrete abode of production' to establish that all four revenue forms derived from the surplus-value created in the circuits of productive capital. In classical and vulgar political economy and lay perception alike, the three 'market prices' (Polanyi) or three/four forms of revenue (Marx) were attributed to the inherent properties of distinct factors of production independently of the process of valorisation of capital in the circuits of productive capital. While these may be illusory, insane categories (as Marx puts it), they have real effects on the movement and relations of money, credit, and capital and, hence, on the distribution of social wealth. For example, as de Brunhoff (1998: 182) observes about interest as the cost of money, "this irrational price is also a factor in the rationalization of individual capitalist practices". This is because "[i]t serves industrial and mercantile capitalists as a prerequisite and a factor in the calculation of their operation" (Marx, 1967c: 368). At the same time it disguises the real mechanisms involved in valorisation and capital accumulation (Marx, 1967c: 814-31).

Treating the historical development of prices and the associated processes of price formation for land, labour, and money as a wholly natural, fully rational process (or progression) in human development leads to the fallacious and fetishistic belief, criticised by Marx, that economic value arises from the immanent, eternal qualities of things rather than from contingent, historically specific social relations. For Polanyi, this development requires the dis-embedding of exchange relations from non-market relations that previously limited and governed their operation and their subsequent re-embedding in a self-regulating market society.

Self-regulation implies that all production is for sale on the market and that all incomes derive from such sales. Accordingly, markets exist for all elements of industry, not only for goods (always including services) but also for labor, land, and money, their prices being called respectively commodity prices, wages, rent and interest. The very terms indicate that prices form incomes: interest is the price for the use of money and forms the income of those who are in the position to provide it; rent is the price for the use of land and forms the income of whose who supply it; wages are the price for the use of labor power, and form the income of those who sell it; commodity prices, finally, contribute to the incomes of those who sell their entrepreneurial services, the income called profit being actually the difference between two sets of prices, the price of the goods produced and their costs, i.e., the price of the goods necessary to produce them. If 
these conditions are fulfilled [in a fully functioning market society], all incomes will derive from sales on the market, and incomes will be just sufficient to buy all the goods produced. (Marx 1977: 69)

However, according to Polanyi, if this threefold (fictitious) commodification goes too far, it will provoke resistance to the market economy from a wide range of social forces adversely affected thereby. He emphasises the tendential disjunction between the logic of the market and the reproduction (renewal) requirements of nature and of labour-power alike, and also explores the effects of dissociating the circulation of money from the requirements of economic exchange for the satisfaction of human needs. This uncoupling, argues Polanyi, generates such powerful contradictions and crisis-tendencies in market economies that 'society' eventually fights back against their environmentally and socially destructive effects. This invites us to consider whether another Great Transformation will result from 'society' fighting back as Polanyi might have anticipated in the face of the current 'triple crisis' (environmental, social, and financial), or whether its outcome will instead confirm Karl Deutsch's (1973: 111) aphorism that power is the ability not to have to learn from one's mistakes.

\section{Further reflections on commodification}

This section develops the concept of fictitious commodity and the next section explores its relevance to monetary relations. To frame the discussion, I distinguish four aspects of the uneven movement of land, labour, and money from non-commodities into fictitious commodities. First, Marx and Polanyi argue that land (or nature), labour-power, and money are not inherently commodities. As non-commodities, they comprise raw nature, human creativity, and natural (or symbolic) tokens of exchange respectively. There is no problem in seeing raw nature as a non-commodity in this regard - it comprises the natural world prior to its appropriation and transformation in and through human labour. Human creativity is also unproblematic - it comprises the innate or learnt capacities of the human species considered individually and collectively to perform useful labour. Even when labour-power has acquired a commodity form (a process that occurs very late in human evolution), it is still reproduced in significant measure through a heterogeneous ensemble of non-market institutions and practices. Lastly, as Polanyi (1977: 62-73) shows from historical and anthropological records, tokens should not be considered as commodities when they are exchanged in equivalencies set outside the market mechanism. Moreover, regardless of the substantive nature of money tokens (natural goods, products such as coin or bullion, or fiduciary symbols without real value), the monetary system in which they circulate cannot be operated solely for profit without regard to other considerations. On the contrary, the very economic functionality of monies depends critically on personal and impersonal trust as well as extra-economic institutions and sanctions.

Second, we can distinguish a simple commodity from a capitalist commodity. A simple commodity is a product (a good or service) that is offered for sale - perhaps with only surplus beyond the immediate needs of the producers being put up for sale rather than the entire production being produced in order to sell it. Goods and services offered for sale can arise from peasant, petty commodity, state production, cooperative production, or social enterprise as well as capitalist production. What distinguishes a capitalist commodity from other kinds is that it is produced in a labour process that is subject to capitalist competition. This creates pressures to reduce the socially necessary labour-time involved in its production and the socially necessary turnover time involved in realising the surplus-value that it embodies. In 
turn this generates a dynamic relation between the organisation of production and the commodity character of the products being produced.

Third, on this basis, a fictitious commodity has the form of a commodity (can be bought and sold) but is not produced in order to be sold. It already exists as a use-value before it acquires the form of an exchange-value (e.g., raw nature) or it is produced as a use-value before being appropriated and offered for sale (e.g., human artefacts originating in a substantive, socially embedded economy). This concept is important because analysing land, money, and labour-power as if they were simple and/or capitalist commodities would obscure the conditions under which they enter the market economy, get transformed therein, and so contribute to the production of goods and services for sale. In this sense, a fictitious commodity belongs to the broader spectrum of quasi-commodities that have a price but otherwise fail to meet one or more of the criteria for a full commodity. A full commodity for Schaniel and Neale (1999: 96) is one that it is produced in factory like ways for sale on a commercial market. I would add that a full capitalist commodity is one where production is subordinated to capitalist competition at all stages in production and distribution to reduce socially necessary labour and turnover times.

Thus, as fictitious commodities, land, labour, and money would comprise: (1) land that has been enclosed and appropriated and then sold or rented in a private commercial transaction with its price reflecting its productive potential and/or market demand; (2) the capacity to perform useful labour reproduced outside the market economy and entering the labour-market from outside in return for a wage; and (3) money as a marketable store of value and medium of exchange, with competing commodity monies (e.g., gold, silver), fiduciary monies (tokens, paper money, bank credits, fiat money), or tradable currencies (e.g., dollars, euros, yen). In each case, what is crucial to their status as fictitious commodities is that they are not produced in order to be sold but have entered into exchange relations because markets in land, labour-power, and monetary tokens have been established. They could also be redistributed in other ways, e.g., territorial conquest, enslavement, requisition or confiscation, direct or indirect reciprocity, and so on.

Fourth, treating land, labour, and money as if they were commodities could lead in due course to their transformation into one or more types of quasi-commodity as each becomes more closely integrated into the cash nexus of market relations. At stake here are the ways in which economic agents engage in formal, rational action to increase the exchange-value of these fictitious commodities, i.e., their price as opposed to their value, through forms of 'investment' that correspond to each so-called factor of production. Examples of this include: investments of capital and labour-power to improve 'land' (reflected in changes in absolute and differential rent); efforts to increase skill levels or re-skill labour-power (considered as marketable 'human capital') and/or to increase its scarcity (e.g., through artificial barriers to labour market entry); and actions to ensure the credibility of money by linking it to real assets (e.g., the recovery from hyper-inflation in the Weimar Republic thanks to the backing of the new German mark through another fictitious commodity, land values). The resulting integration of land, labour, and money into the circuits of capital and their subjection to the competitive pressures of capital accumulation reinforces (and gives a material basis to) the "economistic fallacy' insofar as they become quasi-commodities open to rational calculation and actions to increase the corresponding revenue streams, i.e., rents, wages, and interest.

Fifth, in this context, a further step in commodification would come through the power of abstraction inherent in the extension of capitalist social relations. Thus 'land' could be securitised in terms of future flows of absolute and differential rent (e.g., shares in real estate investment trusts); money could be traded in futures markets and increasingly rarefied 
derivative markets. In these respects, fictitious or quasi-commodities can be transformed into fictive capital, that is, into tradable commodities whose price depends on calculation about discounted future revenues. In this sense they can be assimilated to the category of interestbearing capital as one form of money as property rather than money as functioning capital (see below). An analogous process occurs in relation to labour-power insofar as the logic of capital reduces concrete useful labour to abstract social labour, i.e., leads to the evaluation of labour-power in terms of its contribution to (potential) surplus-value validated through the sale of capitalist commodities (whose value to the capitalist resides in their exchange-value and not their use-value) and not in terms of the specific qualities of the labour-power that is expended in a particular labour-process. This kind of abstraction also occurs theoretically in neo-classical economics, in real terms in institutionalised calculation about future earnings streams (e.g., legal compensation or insurance systems that compensate workers for lost income), and, increasingly, practically, in workers' own calculations about the returns to 'investment' in their own 'human capital' as they become self-responsible (indeed, neo-liberal, self-responsibilised) 'entrepreneurial' subjects who seek to maximise their discounted life-time earnings.

\section{Marx on money and capital}

I have now defined non-commodities, simple commodities, capitalist commodities, quasicommodities, and fictive capital, and considered their relevance to land, labour-power, and money. They can also be applied to the question of whether knowledge can be considered in Polanyian terms as a fourth fictitious commodity (Jessop, 2007). Here, however, I focus on the nature of money in these terms and what follows theoretically and practically from integrating Marx's successively introduced distinctions between money as money, money as functioning capital, and capital in its role as property rather than functioning capital. This poses important questions about the forms and functions of money, their respective inherent crisis potentials, and their changing hierarchical relations. There is neither space nor time here to develop all of the implications of Marx's distinctions and, accordingly, I focus on the issue of whether money is best seen in Polanyian terms as an inherently fictitious commodity. ${ }^{2}$

Marx studied the history of money to establish a benchmark to assess the historical specificity of the forms and functions of money and credit relations in the capitalist mode of production. While several monetary functions and categories are long established (for example, money, credit, usury), they are all transformed by capitalist development (Marx, 1967a: 112, 527; 1967c: 325-37; 1972: 468-70, 485-92). In his discussion of money in $A$ Contribution to the Critique of Political Economy and, later, in Capital I, Marx started with its function as a medium of exchange in simple circulation (as the counterpart to commodities in a commodity-money-commodity or C-M-C transaction) and then added more functions to the analysis of money as money (see Table 1). In the opening chapters of these books, however, Marx had not introduced the concept of money as capital. When he did so, even the functions of money as money identified in earlier chapters are modified as he develops the distinctive features of money as functioning capital and, later still, of capital as property (especially in the form of interest-bearing capital). The crucial extensions concerned how the evolution and operation of credit (in its different forms) modify the circuits of capital. Specifically, credit reduces the need for profit-producing capital to hold monetary reserves, lowers the socially necessary turnover time of capital, and changes the temporalities of the circuits of capital. Marx takes the analysis even further by introducing fictitious money (credit money), commodity-dealing, money-dealing, interest-bearing, and share-dealing capital, the 
intermediary role of banks in the circuits of capital, and fictitious capital (Marx, 1967c: 267322). Overall, he shows that credit relations (especially bank deposits) increasingly replace money (cf. Ingham 2004: 107-43) as the fundamental category for analysing the contradictory unity and crisis-prone dynamic of total social capital.

As Marx moves from the functions of money in simple commodity circulation (where he assumes, for the sake of his opening argument, that money is a real commodity) to its forms and functions in a fully developed capitalist economic formation, he makes three crucial conceptual moves. First, he seeks to show that, in a fully developed capitalist system, money takes the form of increasingly complex forms of credit. Second, he distinguishes (1) real commodities, real money, and real capital from (2) fictitious commodities, fictitious money, and fictitious capital. And, third, he distinguishes money as functioning capital from interestbearing capital as property (on the second and third developments, see Table 2). Unsurprisingly, given his distinctive logical-historical method, these categories are interconnected both conceptually and in their historical movement.

In this regard money is a representation of value (and/or of credit-debt relations) and it can also function as capital, either as the most general expression of capital in the abstract vis-à-vis specific forms of capital and/or as a money commodity (for example, gold) or, again as a fictitious commodity, tradable against other commodities (including other national monies in currency markets). Likewise, while Marx initially assumed that money was a real commodity (that is, the raw material of the money commodity was produced in a capitalist labour process and transformed into coins and bullion), this assumption was relaxed as he explored other forms and functions of money. Indeed, he argued that the expansion of capitalist social relations required that gold no longer be used in domestic circulation (Marx, 1967c: 517).

In particular, for Marx, when money is transformed into functioning capital, it mediates the core social relation of capitalism, that between capital and wage labour. Indeed, money as capital expresses the power of capital to organise and control labour-power in production.

The labour process has a dual character: it involves both the appropriation and transformation of nature and the valorisation of labour-power. Money's role as functioning capital reinforces the transition from social production based on householding and/or political redistribution and/or simple exchange relations (Polanyi, 1957) into a capitalist economy in which private and public credit and banking relations increasingly replace real and/or paper money as the basis of accumulation (Marx, 1967a-c; 1969). This development moves society beyond credit-money that is advanced to finance consumption (usury) and/or state activities (public debt) to the functioning of credit-money as capital. Theoretically, this underlines the need for analytical categories specific to the circulation of money as capital and its various forms. Further conceptual elaboration is required by the rise of fictitious capital and its status as property. In this regard it differs from functioning capital, that is, capital that is employed directly in production or circulation (see Table 2)

This leads Marx to stress the duality of money as both a real commodity and a fictitious commodity, and its dual foundation in the social relations of commodity production and in social relations of trust. This poses the question of the respective roles of money as a real commodity and as a fictitious commodity in performing the functions of money as money and money as capital. Marx analyses metallic and non-metallic money as complementary counterparts, "united through the inherent contradiction between the need of capital to expand indefinitely and the need for money to be universalizable exchange value, i.e. bound to real value production and its realization in trade" (Krul, 2010: 5). In short, the duality of money implies major tensions, potential contradictions, and crisis-potentials that are expressed in the overall dynamic of capital accumulation and public finance. 
First, considered as a real commodity, money emerges spontaneously from the logic of commodity circulation. In this context, its value is determined by the socially necessary labour time involved in its production (Marx, 1967a: 99-100; see also Stemmet, 1996). Likewise, its price is overdetermined by demand for the money commodity and the dynamic of absolute and differential rent involved in gold and silver production in panning and mining sites with different unit costs (Marx, 1967b; 1969). Together these constitute the value-space of real money, i.e., the production of the money commodity and its hoarding or circulation as real money.

Table 1. Marx on the functions of money. Source: Author's compilation, based in part on Marx (1967a, 1969, 1970, 1972); modified to distinguish MH more clearly from $\mathrm{MH}(\mathrm{K})$ and to identify MMI.

\begin{tabular}{|c|l}
\hline Function & \multicolumn{1}{c}{ Definition } \\
\hline MMC & Means of circulation (exchange) \\
\hline MMV & Extrinsic measure of value (price); Imaginary measure (numéraire) \\
\hline MH & Store of value (as simple hoard) \\
\hline MM & $\begin{array}{l}\text { Simple money as unity of MMC + MMV, i.e., } \\
\text { money as general equivalent }\end{array}$ \\
\hline MH(K) & $\begin{array}{l}\text { Store of value (as capital) } \\
\text { Commodity capital of producers of money commodity (e.g., gold) } \\
\text { International reserve currency }\end{array}$ \\
\hline MMP & $\begin{array}{l}\text { Means of (deferred) payment, 'money proper', money as money (i.e., } \\
\text { commercial and payment credit as functioning capital) }\end{array}$ \\
\hline MMI & $\begin{array}{l}\text { Money as interest-bearing capital lent to industrial and commercial capitalists } \\
\text { as functioning capital }\end{array}$ \\
\hline MCC & Money-form of circulating capital (e.g., reserve for salaries, current purchases) \\
\hline WM & Money as world money, i.e., means of international payment \\
\hline Key & \multicolumn{2}{|c}{} \\
\hline & Functions logically prior to MM \\
\hline & Money as unity of these functions \\
\hline
\end{tabular}

However, if the supply of metallic money does not keep pace with the actual (let alone potential) production of commodities, then the self-valorisation of capital (its expanded reproduction) will be limited. As this gap is normal given capital's appetite for boundless expansion, capital detaches the supply of money from its metallic base by resorting to credit and fiat monies. In these circumstances, the raw material of real money becomes little more than the commodity capital of its specialised producers to be exchanged for other commodities against payment in non-commodity money (MMC). The money commodity may continue as part of the money capital of banks, central banks, or states (MMH) and, in the form of bullion, plays a key role, alongside central bank monies (notably international reserve currencies, with or without real monetary backing in the form of bullion) in the functioning of world money (WM).

In contrast with bullion or other forms of commodity money, different quantities of credit and fiat money do not meaningfully embody different amounts of labour-time. It involves no more labour-time to print a high- than a low-denomination banknote and little more to create a billion- than million-dollar security. In short, credit and fiat money do not embody value. 
Nonetheless they do represent or reflect value in the sense that they comprise claims on social wealth insofar as this takes the form of an immense accumulation of commodities (Marx, 1967a). Their acceptability as money depends on relations of trust based on accepted banking principles and/or state guarantees (Krätke, 2005). Moreover, given the hierarchy of money forms (see Table 3), state authority replaces the value-space as the ground of money's acceptability (Park, 2010: 8). The precise relations among private bank credit, central bank credit, and state fiat money vary historically as well as within and across national states and the world market (see below on currency pyramids). Nonetheless the distinction between central bank credit money and state fiat money is crucial to Marx's analysis. The state makes fiat money acceptable (validates it) because it can be used to pay taxes (cf. Marx, 1967a: 52832). Yet the state's role in detaching money from a metallic base is "fundamentally constrained and limited by the inherent requirement for maintaining the quantity [and circulation] of [non-commodity] money at a level that corresponds to the dynamics of capital accumulation" (Park, 2010: 17). This is the basis of the monetarist critique of the state's debasement of the national currency as well as of liberal and neo-liberal demands for central bank independence. More generally, the distinction between credit and fiat money is crucial to Marx's analysis of the contradictions, dilemmas, and crises of the forms and functions of money in capitalist social formations (cf. Krul, 2010: 15)

Table 2. Marxian categories for the analysis of money, credit, and capital. Source: Author's compilation, based in part on Marx.

\section{'Real' categories}

Real Commodity = Unity of use- and exchange-value produced in circuits of profit-producing capital and circulating in M-C-M'

Real Money $=$ The money commodity produced in the above circuit: it mediates C-M-C and M-C-M'

Real capital $=$ Profit-producing capital

Note: These categories are logically prior to their fictitious counterparts; as the latter evolve, real and fictitious forms may be opposed.

\section{Capital as functioning capital}

Productive ('industrial' or profit-producing) capital (constant and variable)

Circulation capital (commodity and money capital, including the money commodity, e.g., coin, bullion)

Merchant's capital (commodity-dealing and money-dealing capital) when performs necessary functions in reducing turnover time of capital as a whole

Note: Interest-bearing capital is included here insofar as it functions as capital in relation to the operation of the forms listed.

\section{Capital as property}

Interest-bearing capital (titles of ownership, financial assets) that circulates as self-increasing money or capital, i.e., as source of revenue

This becomes fictitious capital when priced in terms of capitalised discounted income streams; it can then be traded in specialised markets

Capital-dealing capital (e.g., for sale and purchase of stocks, shares, and other financial assets)

\section{Fictitious capital (narrowly defined)}

Money lent as MMC directly or via banks to states (e.g., for wars, public spending)

Fictitious capital-dealing capital (i.e., capital that deals in fictitious capital) 
Interest-bearing capital is the most fetish-like form of money because interest makes it appear that capital, not labour-power, creates surplus value, rather than interest being a deduction from value created in production. This has several consequences analysed by, among others, Polanyi and Marx. For Polanyi, it leads to growing indebtedness and social alienation and, sooner or later, to the 'fight back' of society. For Marx, it changes the dynamics of class conflict because the rate of profit now forms an antithesis not with wage labour but with the rate of interest (Marx, 1967c: 370-90). This leads to conflicts between fractions of capital, especially between profit-generating capital and interest-bearing capital. This is particularly acute when interest-bearing capital is dissociated from the real production and realisation of value in the metamorphosis of profit-generating capital (e.g., in funding the purchase of fixed capital or providing trade credit). This dissociation can occur in the short- to medium-term when private credit expansion is directed to speculation and Ponzi finance, shadow banking expands, there is increasing reliance on leverage unrelated to the real movement of value, and prudential state controls are weak or absent. But the real movement of capital will sooner or later re-impose itself.

According to Minsky's financial instability hypothesis, unusually long periods of relatively stable growth encourage false optimism. This leads economic actors to borrow excessively and to pay inflated prices for assets. Prudent investors who had hitherto engaged only in hedging finance (in other words, who expected to meet all their debt obligations, i.e., interest and principal, from reliable cash flows) become less risk-averse and/or new investors are seduced to enter financial markets using borrowed money. This is the stage of easy credit that sustains speculative finance in which interest payments can be met from cash flow but capital repayments now depend on asset appreciation - with the result that, if economic movements do not turn out as anticipated, speculative borrowers may have to take fresh loans to repay the original loan. A third stage, marked by yet easier credit based on Ponzi finance, emerges when even the repayment of interest depends on continuing asset price inflation that enables Ponzi borrowers to refinance a debt whose eventual repayment is always being postponed. Over the course of a cycle, huge portfolios of financial instruments are accumulated and levered and an increasing proportion of these portfolios are based on Ponzi finance. Minsky (1992) added that, over the course of a financial cycle (from hedging through speculative to Ponzi finance), financial institutions, which also become less risk averse, engage in financial innovation to get round regulations and prudential controls intended to prevent speculative frenzies because they expect the boom to last.

A Minsky moment is the point in a business and/or credit cycle when over-indebted investors are forced to sell good assets to repay their loans, causing sharp declines in financial markets and hikes in the demand for cash. This leads in turn to a liquidity and even solvency crisis, which can force central bankers to extend credit (Minsky, 1975; 1982; 1986; 1995). The result is a one-sided sellers' market and market collapse - sometimes called a 'Minsky meltdown' - unless bankers or other economic actors come to the rescue. It is in this context that there is a scramble for 'hard cash' or, at least, more credible forms of credit backed by more credit-worthy institutions with strong reserves. Or, as Marx expressed it in Capital III:

In times of a squeeze, when credit contracts or ceases entirely, money suddenly stands as the only means of payment and true existence of value in absolute opposition to other commodities. Hence the universal depreciation of commodities, the difficulty or even impossibility of transforming them into money, i.e., into their own purely fantastic form. ... A depreciation of credit-money (not to mention, incidentally, a purely imaginary loss of its character as money) would unsettle all existing relations. Therefore, the value of commodities is sacrificed for the purpose of safeguarding the fantastic and independent existence of this value in money. As money-value, it is secure only as long as money is secure. For a few millions in money, 
many millions in commodities must therefore be sacrificed. This is inevitable under capitalist production and constitutes one of its beauties. (Marx, 1967c: 649)

Thus Minsky cycles end in a pro-cyclical flight to safety, "a violent scramble for means of payment" (Marx, 1981: 621), a 'dash for hard cash', which some call a Minsky moment. ${ }^{3}$ This threatens a downward spiral of debt-default-deflation. This dynamic can be understood in terms of a shift in the role of money as capital from functioning capital towards capital as property. In Minsky's analysis, the role of hedging in the expansion of economic activities can be seen as one aspect of money as functioning capital. In contrast, in speculative and Ponzi finance, money operates in the guise of capital as property, i.e., as loan-bearing capital. Marx also suggested that the advance of credit is critical to the expanded reproduction of capital (serving to pre-validate investment and production - Minsky's hedging role - but vulnerable for the same reason to ruptures in the C-M-C and M-C-M' circuits). He added that a period of growth facilitated in this way encourages further expansion of credit-debt relations. However, an increasing volume of credit-debt also makes the economy more vulnerable, that is, "oversensitive" to the eventual downturn (Marx, 1981: 706). The mechanisms involved in this downward spiral are related to the profit-oriented, market-mediated operations of the capitalist mode of production and, in this context, to the hierarchical relation among money forms (see also Rasmus, 2010).

\section{The hierarchy of money forms and currency pyramids}

This hierarchy facilitates the displacement and deferral of contradictions in the capital relation in general and in money forms and functions in particular. We see this in central banks' role as lender of last resort in national contexts and in the role of state fiat money in bailing out private banks and guaranteeing central bank debt (thanks to state's taxing capacities and, where relevant, money-issuing powers). That there are limits to such displacement-deferral mechanisms has been demonstrated once again in the NAFC in the growing disproportions among: (1) the explosion of fictitious money and fictitious capital; (2) the expansion of the 'real' economy on which these fictitious forms are claims; and (3) state capacities to issue fiat money and tax their populations to absorb 'toxic' debt, which is the (im)polite name for what Marx termed 'excess credit', rather than using other capacities to prevent its development or ensure its devalorisation. It is these disproportions that, coupled with the power of financial capital to shape national, European, and supranational state policy, that have transformed a crisis of 'excess credit' into a crisis of public and sovereign debt. This crisis has provided, in its turn, the fisco-financial and ideological basis for a reinvigorated neo-liberal assault on the (welfare) state in the name of austerity. This assault is a significant indicator of the power of finance in an era marked by the rise of finance-dominated accumulation (see also Jessop, 2013a; Lapavitsas, 2013).

More generally, although credit and fiat money enable capital to escape the limit imposed by commodity money ('hard cash') on expanding production, it re-emerges at a world level, even in the absence of Ponzi schemes. For, there is no world state or legal authority to set a price numéraire as a unit of account or commensuration, and to authorise fiat money to ensure the acceptability of non-commodity money (Krul, 2010; Park, 2010). This is already implicit in Marx's discussion of world money (bullion) and his remarks on the flight to gold when other forms of money - including fiat money backed by even the previously most creditworthy state - lose credibility. 
Table 3. The hierarchy of money forms. Source: Author's compilation, partly based on Marx.

\begin{tabular}{|c|l|l|}
\hline Form & \multicolumn{1}{|c|}{ Content } & \multicolumn{1}{|c|}{ Material or Social Validation } \\
\hline Commodity & $\begin{array}{l}\text { Physical commodity } \\
\text { (Metallic money as the pristine } \\
\text { form of money, real money) }\end{array}$ & $\begin{array}{l}\text { Embodied value (labour-time } \\
\text { involved in production of the money } \\
\text { commodity) }\end{array}$ \\
\hline $\begin{array}{c}\text { Bill of } \\
\text { Exchange }\end{array}$ & $\begin{array}{l}\text { Notes and tally sticks as symbolic, } \\
\text { token, or paper money: early forms } \\
\text { of commercial credit (with no } \\
\text { interest charged or paid) }\end{array}$ & $\begin{array}{l}\text { Convertibility (ease of translation into } \\
\text { coin or bullion or another valid form } \\
\text { of money or credit) }\end{array}$ \\
\hline $\begin{array}{c}\text { Bank Credit } \\
\text { (private) }\end{array}$ & $\begin{array}{l}\text { Bank notes and deposit money as } \\
\text { basis of bank IOUs, (credit money } \\
\text { or fictitious money, interest paid on } \\
\text { credit) }\end{array}$ & $\begin{array}{l}\text { Convertible into coin or bullion } \\
\text { and/or guaranteed by state }\end{array}$ \\
\hline $\begin{array}{c}\text { Central } \\
\text { Bank Credit }\end{array}$ & $\begin{array}{l}\text { Advanced by central bank as lender } \\
\text { of last resort }\end{array}$ & $\begin{array}{l}\text { Convertible into gold at central bank } \\
\text { or guaranteed by state. } \\
\text { If it is convertible, can be part of } \\
\text { international reserves (hoards) }\end{array}$ \\
\hline $\begin{array}{c}\text { State } \\
\text { Money }\end{array}$ & $\begin{array}{l}\text { Fiat money (central bank notes, } \\
\text { legal tender, government bonds) }\end{array}$ & $\begin{array}{l}\text { Taxation, coercion, credibility or } \\
\text { sheer extractive power }\end{array}$ \\
\hline $\begin{array}{c}\text { World } \\
\text { Money }\end{array}$ & Bullion as pristine form of WM & \begin{tabular}{l} 
Bullion, dollar standard, etc. \\
\hline
\end{tabular} \\
\hline
\end{tabular}

In this light, let us turn to the nature of world money. The hierarchy of money forms presented in Table 3 (above) has a physical commodity at its base and summit - respectively commodity money and bullion. Further, while other forms of money had to develop so that the limits to capitalist expansion set by commodity money could be broken, this limit could re-emerge at the level of the world market because there is insufficient bullion in the world to validate the expansion of credit and there is no lender in the last resort or world state to guarantee the validity of credit.

But this logic may not hold if some monetary functions in the world market can be secured without a world state. We can explore this through the notion of a currency pyramid. Michel Aglietta identified a tension between the inherent plurality (pluralité) of national currencies and the necessary uniqueness (unicité) of world money. Since the full range of money functions could not be secured through bullion and, absent a world state that could lend credibility to a true world money, a partial, provisional, and unstable solution could be to adopt as world money the currency of the hegemonic or dominant state, where one exists (Aglietta, 1987). This may be viable in situations where the hegemonic currency is convertible with gold (for example, the Bretton Woods gold-dollar standard), but is vulnerable to Triffin's dilemma. This is the problem faced by reserve currency issuers in pursuing domestic monetary policy goals while meeting other countries' demand for reserve currency (Triffin, 1961).

Parallel reasoning led Susan Strange to a more nuanced account of the currency pyramid in which the circulation of national currencies and their potential as world money had different social bases. She defined this pyramid in terms of the balance of market forces and state power in shaping the role of currencies in national, regional, or world markets (Strange, 1971a; 1971b). However, while Strange argued that market forces selected the top currency, its issuing state also sustains it through its state capacities, including hard and soft power abroad as well as domestic measures to maintain the competitiveness of domestic and/or overseas investments. In practice, of course, currencies can combine features of the first three forms, depending on geo-economic and geo-political factors and forces. For example, while the USD is both a top and master currency, the Euro is both a master currency (linked to German 
mercantilism) and a negotiated currency (linked to a subset of European member states and tied to a political project) (see Lapavitsas, 2012).

The currency pyramid is significant in terms of the asymmetrical organisation of the world market, whether the latter is seen in terms of a logic of territorial expansion or in terms of the logic of a space of flows (see Table 4). Different currencies are differently situated in this regard. In the absence of a world money (or, at least, in the case of bullion, a world money that exists in sufficient quantity to perform the functions of money on a world scale), and in the absence of a world state (or, at least, an imperial state secure in its global hegemony), the top currency plays a crucial but contradictory role in the integration of the world market, especially when the top currency is central to the development of finance-dominated accumulation (and hence an important factor of crisis-generation) and also serves as a safe haven in the flight to quality as the crisis erupts and intensifies. The crisis in the Eurozone and the absence of conditions for an effective challenge from the Yen or Renminbi as alternative top currencies mean that the USD remains the pre-eminent form of 'world money', even as it is also implicated in the generation of the financial crisis.

Table 4. The currency pyramid. Source: Author's compilation, based in part on Strange (1971a; 1971b).

\begin{tabular}{|c|l|}
\hline Form & \multicolumn{1}{c}{ Features } \\
\hline Top Currency & $\begin{array}{l}\text { Issued in and/or backed by the state that enjoys world economic } \\
\text { leadership, i.e., the dominant state in world market }\end{array}$ \\
\hline $\begin{array}{c}\text { Master } \\
\text { Currency }\end{array}$ & $\begin{array}{l}\text { Circulates mostly in geo-political blocs, e.g., thanks to political dominance of } \\
\text { issuing state }\end{array}$ \\
\hline $\begin{array}{c}\text { Negotiated } \\
\text { or political } \\
\text { currency }\end{array}$ & $\begin{array}{l}\text { Tied to international regimes with emphasis on mutual benefits rather than } \\
\text { coercion }\end{array}$ \\
\hline $\begin{array}{c}\text { Passive or } \\
\text { neutral } \\
\text { currency }\end{array}$ & Circulates domestically, minor role in international regimes \\
\hline
\end{tabular}

Table 5. Money and derivatives. Source: Author's compilation, based largely on Bryan and Rafferty (2006).

\begin{tabular}{|c|l|l}
\hline Function & \multicolumn{1}{|c|}{ Definition (Marx) } & \multicolumn{1}{c}{ Derivatives } \\
\hline MMC & Means of circulation (exchange) & Forward currency derivatives \\
\hline MMV & $\begin{array}{l}\text { Measure of value (role of money } \\
\text { commodity or official standard of } \\
\text { price) vs. imaginary unit of } \\
\text { measure (numéraire) }\end{array}$ & $\begin{array}{l}\text { Potentially universal commensuration } \\
\text { of real and fictitious commodities, } \\
\text { real and fictitious money, and real } \\
\text { and fictitious capital, without single } \\
\text { MMV }\end{array}$ \\
\hline MH & $\begin{array}{l}\text { Store of value (hoard, then } \\
\text { capital) }\end{array}$ & $\begin{array}{l}\text { Hedging against depreciation, } \\
\text { commodity speculation }\end{array}$ \\
\hline MMP & $\begin{array}{l}\text { Means of (deferred) payment, } \\
\text { 'money proper', money as money }\end{array}$ & Securitisation, credit swaps, etc. \\
\hline MMI & $\begin{array}{l}\text { Money as interest-bearing capital } \\
\text { Money as independent value, i.e., } \\
\text { concentrated form of total capital }\end{array}$ & $\begin{array}{l}\text { Securitisation of capital as property, } \\
\text { interest rate swaps, arbitrage }\end{array}$ \\
\hline WM & $\begin{array}{l}\text { Money as world money, i.e., } \\
\text { means of international payment }\end{array}$ & $\begin{array}{l}\text { Currency arbitrage based on plurality } \\
\text { of currencies }\end{array}$ \\
\hline
\end{tabular}




\section{A brief digression on derivatives}

Most forms of money lack intrinsic value. This is especially true of interest-bearing capital and, above all, derivatives as they currently operate in the era of finance-dominated accumulation. As Carchedi (2011) notes:

[T] he basic object of ... transactions [in interest-bearing capital] is a representation of debt rather than of value. It engages in transformations from a representation of value (for example, money) into a representation of debt (bonds, derivatives, etc.), from a representation of debt into a different form of representation of debt (from mortgages into mortgage-backed securities), or from a representation of debt into a representation of value (the sale of a mortgage). These representations of debt are called by Marx fictitious capital.

Just as there are inherent constraints on the state's ability to create fiat money before monetary crises emerge, so there are limits to banks' ability to continue to create credit before monetary and credit crises arise. This can be seen in the development of securitisation and, especially, the rise of derivatives and their massive expansion. For, as Marx anticipated (not only in his remarks on the world market but also in his remarks on fictitious capital and the contradiction between capital as value in motion and capital as property), this generalises and intensifies competition in relation to the means of production, money capital, specific capitals as units of competition, and social capital. Derivatives are the most generalised form of this capacity and, based on the calculation of value-at-risk (VaR), they have a growing role in the commensuration of all investment opportunities and every single risk in the world market (Bryan and Rafferty, 2006). In extending and deepening the basis for hedging and financial speculation, derivatives play a key role in the tendential completion of the world market by transforming future income streams (profit, dividend, or interest) into tradable assets, and also change the dynamics of competition on a world scale (Table 5).

Noting the arguments of Marx and Engels in The German Ideology (1979) on the limits to world market integration, we could say that derivatives as forms of financial innovation integrate production on a world scale, for they tend to:

- Overcome the frictions of national boundaries;

- Open national economies to foreign competition;

- Help to overcome the clumsiness of production; and

- Enhance the role of finance in promoting competition.

Thus, in so far as derivatives promote the completion of the world market, they also serve to activate 'all the contradictions' of capital accumulation (see Marx 1976b; 1973; and Marx and Engels 1976).

Financial innovation has vastly increased the amount of leverage in the system. Contrary to Minsky's view that households relied on hedge finance to sustain their consumption and to purchase housing, it has enabled them to engage in speculative and Ponzi borrowing on a massive aggregate scale - encouraged to do so through lenders' new-found ability to securitise these loans and offload their risks. Among other effects, these "financial weapons of mass destruction" (Buffett, 2003: 16) multiply the volume of opaque, highly leveraged, largely unregulated financial transactions. This overwhelms the capacity of central banks to act as lender of last resort and/or has prompted the socialisation of toxic assets at fictitious prices (compared to their mark-to-market valuation) and the transformation of private Ponzi debt into public and/or sovereign debt. This has changed the forms of appearance of the crisis 
and the allocation of its costs and consequences, but it has not resolved the potential for crisis in capitalism, notwithstanding Greenspan's views on the efficient market hypothesis and the self-interest of financial institutions in prudential activities to avoid putting their capital and social reputation at risk through control fraud, speculation, Ponzi finance, and 'unusual deals with political authority' (see Jessop, 2013b). The expansion of these markets (especially when hidden in shadow banking activities or conducted offshore) means that they now dwarf the role of financial intermediation and risk-management, and therefore play a pro-cyclical, heavily de-stabilising role via financial speculation and risk-taking by highly leveraged financial institutions (see Broadbent, 2011; Haldane and Alessandri, 2009). It is hardly surprising, therefore, that they played a crucial role in the NAFC and its global repercussions, inflating the financial bubble to a degree unimaginable to the layperson and hard to calculate even for experts. ${ }^{4}$

In addition, derivatives take the fetish-like character of fictitious capital to new heights because they have even less relation than interest-bearing capital to the movement of real values. Indeed these forms of fictitious capital provide the basis for new fictitious commodities (derivatives treated as commodities), new forms of fictitious money (based on securitisation), new forms of fictitious banking capital (for example, more or less rarefied CDOs), and new forms of share capital (for example, credit derivatives product companies, special investment vehicles). These developments are consistent with Marx's unfolding, but never completed, analysis of fictitious commodities, fictitious money, and fictitious capital. But they take them to more rarefied, insane, and irrational heights (think CDO3 and, indeed, so-called CDOn). Underpinning these developments is, as McNally notes:

\begin{abstract}
[an] attempt to create something called abstract risk that can be measured and sold. This is what derivative markets do, they buy and sell risk exposures ... The assumption built into it is something inherent in the value abstraction - the idea that all these risks are commensurable and equitable. This is what exploded, as it had to, because it carries all the inherent contradictions of the value form - the contradictions between the concrete actual processes of social organisation of life activities within capitalism and the value form. (McNally, 2011: 115)
\end{abstract}

Before this explosion, however, and, indeed, afterwards, these developments also modify the forms of competition. Derivatives reinforce the separation between the general movement of capital based on valorisation and the fluctuation of money prices and profit and, in this way, facilitate financialisation and the rise of finance-dominated accumulation. The disembedding of financial capital and the extension of neo-liberalism tend to make financialisation the primary basis of differential accumulation and to produce finance-dominated accumulation regimes in which "profit making occurs increasingly through financial channels rather than through trade and commodity production" (Krippner, 2005: 174; see also Jessop, 2013b). The logic of financialisation (wherever it occurs) transforms the role of finance from its conventionally-defined, if always crisis-prone, intermediary function in the circuit of capital to a more dominant role oriented to rent extraction through financial arbitrage and innovation. It is through the expansion of derivatives, initially for risk management - but, following Haldane (2012), creating opportunities thereby for financial speculation and risk-taking - that the contradictions of the value form find new or intensified expressions. This reflects the paradoxical role of derivatives in risk management, crisis-transmission, and crisismanagement in the sense that, as many have recently observed, the micro-level security offered through securitisation creates macro-level insecurity (e.g. Amato and Fantacci, 2011). 


\section{Conclusions}

Concluding remarks are not the place for a detailed analysis of the genesis, aetiology, and path of the NAFC. This said, it can be summarised as a crisis triggered by growing problems rooted in a hypertrophied finance-dominated economy in which fictitious money, fictitious credit, fictitious capital (and, increasingly, fictitious profits derived from control fraud in various financial institutions) played an increasingly autonomous role in economic dynamics. The overaccumulation of interest-bearing capital enabled by its dissociation from, and indifference to, other moments of the capital relation was a crucial factor in the eventual bursting of financial bubbles around the world. Such bubbles have occurred before, of course, but the present crisis has a more specific, intense form due to the hyper-financialisation of advanced neoliberal economies and, notably, to practices of de-regulated, opaque, and sometimes fraudulent financial institutions that benefit from a corrupt relation with political authority. This created, as eventually it was bound to do, the implosion of the financial bubble, creating the conditions for debt-default-deflation dynamics. This evolved stepwise as the US crisis passed through stages: credit crunch, liquidity crisis, some financial insolvencies, a generalised financial crisis, a recession that risked becoming an epic recession or even great depression, and, most recently, a 'public debt' crisis. A similar trajectory is found in the UK. It is in these circumstances that the shift from the largely unregulated extension of easy credit is transformed into the scramble for hard cash.

The crisis of finance-dominated accumulation regimes in the UK and USA did not produce a crisis of neoliberalism. Indeed, the only example of this is Iceland, where the weight of the hypertrophied financial sector was even more excessive than in the UK, and where radical measures were taken to impose the costs of crisis-management on financial capital (Cyprus came later as part of the Eurozone crisis). In the two Anglo-Saxon economies, however, while financial capital may have lost some credibility, it remained dominant in the accumulation regime, in the state apparatus, and, for the USA, in the legislature. It could therefore exploit the crisis, making sure that it did not, in Rahm Emanuel's terms, 'go to waste'. Where financedominated accumulation drives economic expansion and financial capital is a significant part of the economy (and strongly interconnected with other sectors), financial crisis becomes a source of problems that must be addressed to restore the logic of accumulation. If financial capital is well-entrenched in the state apparatus, then the capacity to rescue 'too big to fail' financial institutions also exists when states can create fiat money and engage in other credit manoeuvres to socialise toxic assets and losses. And when financial capital is also dominant in the power bloc, it can manoeuvre to delay, dilute, and otherwise weaken attempts to reregulate its operations. The costs for this are transferred to the state and this, in turn, provides the opportunity (also not to be allowed to go to waste) of doubling up on the neoliberal vilification of the state, to cut entitlement programmes, and roll out further austerity measures.

In short, a crisis of finance-dominated accumulation has been transformed into a drawnout crisis in finance-dominated accumulation. This was possible because the neoliberal project experienced only a temporary crisis in its onward march. Given the continued dominance of interest-bearing capital in the two advanced economies that had undergone the most radical neoliberal regime shifts (the USA and the UK), the response to the NAFC was to resort to exceptional measures that rescued too-big-to-fail banks rather than providing relief to households with underwater mortgages and distressed debt and/or supporting profitgenerating capital. This transformed the toxic debt of financial institutions into sovereign debt and provided the spurious legitimation for austerity measures in which state efforts to reduce 
public deficits have created debt-default-deflation dynamics that impose hard times as governments impose welfare retrenchment and other austerity measures, leaving households short of hard cash and with limited opportunities to access easy credit.

\section{Notes}

1. On early forms of money and their ties to debt and the state, see Graeber (2010).

2. For a broader discussion of Marx's theory of money, see Jessop (2013a), de Brunhoff (1976), Nelson (1999), Lapavitsas (2013), and Moseley (2005).

3. On the affinities between Marx and Minsky, see Crotty (1985).

4. Although there is no central register of derivatives, recent calculations suggest that the total global stock of notional (non-cleared) derivatives (exercised or not, regardless of term) has reached one quadrillion USD, which is 20 times global GDP.

\section{References}

Aglietta, M. (1987) La Fin des Devises-Clés: Essai sur la Monnaie. Paris: Découverte. Amato, M. and Fantacci, L. (2011) The End of Finance. Cambridge: Polity.

Broadbent, B. (2012) Deleveraging. Speech. 15 March, London. Available at: <http://www.bankofeng land.co.uk/publications/Documents/speeches/2012/speech553.pdf>. Accessed 19 December 2013. Bryan, D. and Rafferty, M. (2006) Capitalism with Derivatives: A Political Economy of Financial

Derivatives. Basingstoke: Palgrave.

de Brunhoff, S. (1976) Marx on Money. New York: Urizen Books.

Buffet, W.E. (2003) Chairman's Letter. In: Berkshire Hathaway Inc. 2002 Annual Report. Omaha:

Berkshire Hathaway Inc.

Carchedi, G. (2011) Behind and Beyond the Crisis. International Socialism Journal, 132: 121-155.

Crotty, J. (1985) The Centrality of Money, Credit and Financial Intermediation in Marxist Crisis Theory.

In: Resnick, S. and Wolff, R. (eds.) Marxian Political Economy. New York: Autonomedia.

Deutsch, K. (1973) The Nerves of Government. New York: The Free Press.

Graeber, D. (2010) Debt: The First 5000 Years. New York: Melville Books.

Haldane, A. (2012) The Doom Loop. London Review of Books, 34(4): 21-22.

Haldane, A.G. \& Alessandri, P. (2009) Banking on the State. Basel: Bank of International Settlements

[online]. Available at: <http://www.bis.org/review/r091111e.pdf>. Accessed 20 April 2013.

Ingham, G.K. (2004) The Nature of Money. Cambridge: Polity.

Jessop, B. (2007) Knowledge as a Fictitious Commodity: Insights and Limits of a Polanyian Perspective.

In: Buğra, A. and Ağartan, K. (eds.) Reading Karl Polanyi for the 21st Century: Market Economy as

a Political Project. Basingstoke: Palgrave.

Jessop, B. (2013a) Credit Money, Fiat Money and Currency Pyramids: Reflections on Financial Crisis

and Sovereign Debt. In: Harcourt, G. and Pixley, J. (eds.) Financial Crises and the Nature of

Capitalist Money. Basingstoke: Palgrave-Macmillan.

Jessop, B. (2013b) The North Atlantic Financial Crisis and Varieties of Capitalism: a Minsky and/or

Marx moment? And perhaps Max Weber too? In: Fadda, S. and Tridico, P. (eds.) Financial Crisis,

Labour Markets and Institutions. London: Routledge.

Krätke, M.R. (2005) Critique of Public Finance: The Fiscal Crisis of the State Revisited [online].

Available at: <http://www.theseis.com/synedrio/05_a_Kraetke.pdf>. Accessed 19 December

2013.

Krippner, G.R. (2005) The Financialization of the American Economy. Socio-Economic Review, 3(2): 
173-208.

Krul, M. (2010) Marx and Monetary Theory. Notes and Commentaries [online], 19 December. Available at: <http://mccaine.org/2010/12/19/marx-and-monetary-theory>. Accessed 19 December 2013. Lapavitsas, C. (2012) Crisis in the Eurozone. London: Verso.

Lapavitsas, C. (2013) Profiting without Producing: How Finance Exploits All. London: Verso.

McNally, D. (2011) Marx, Marxists and the Financial Forms of the Crisis. International Journal of Management Concepts and Philosophy, 5(2): 112-17.

Marx, K. (1976) Speech of Dr Marx on Protection, Free Trade, and the Working Classes. In: Marx-Engels Collected Works, vol. 6. London: Lawrence and Wishart [1847].

Marx, K. (1967a) Capital, vol. 1. Third edition. London: Lawrence and Wishart. [1883].

Marx, K. (1967b) Capital, vol. 2. London: Lawrence and Wishart [1893].

Marx, K. (1967c) Capital, vol. 3. London: Lawrence and Wishart [1894].

Marx, K. (1969) Theories of Surplus Value, Part II. London: Lawrence and Wishart [1862-63].

Marx, K. (1970) A Contribution to the Critique of Political Economy. London: Lawrence and Wishart [1859].

Marx, K. (1972) Theories of Surplus Value, part III. London: Lawrence and Wishart [1862-63].

Marx, K. (1973) Grundrisse: Foundations of the Critique of Political Economy. Harmondsworth: Penguin [1858].

Marx, K. and Engels, F. (1976) The German Ideology. In: Marx-Engels Collected Works, vol. 5. London: Lawrence and Wishart [1845-46].

Minsky, H.P. (1975) John Maynard Keynes. New York: Columbia University Press.

Minsky, H.P. (1982) Can "It" Happen Again? Essays on Instability and Finance. New York: M.E. Sharpe.

Minsky, H.P. (1986) Stabilizing an Unstable Economy. New Haven: Yale University Press.

Minsky, H.P. (1992) Schumpeter and Finance. In: Biasco, S., Roncaglia, A. and Salvati, M. (eds.) Market and Institutions in Economic Development. Basingstoke: Macmillan.

Minsky, H.P. (1995) Longer Waves in Financial Relations: Financial Factors in the More Severe

Depressions II. Journal of Economic Issues, 29(1): 83-96.

Minsky, H.P. (1996) Uncertainty and the Institutional Structure of Capitalist Economies. Journal of Economic Issues, 30(2): 357-68.

Moseley, H. (ed.) (2005) Marx's Theory of Money: Modern Appraisals. Basingstoke: Palgrave.

Nelson, A. (1999) Marx's Concept of Money: The God of Commodities. London: Routledge.

Park, H.W. (2010) Endogeneity of Money and the State in Marx's Theory of Non-Commodity Money [online]. Available at: <http://www.peri.umass.edu/fileadmin/pdf/conference_papers/newschool/ Park_2010._noncommodity_money.pdf>. Accessed 19 December 2013.

Polanyi, K. (1957) The Great Transformation: The Political and Economic Origins of our Time. Boston: Beacon.

Polanyi, K. (1977) The Livelihood of Man. New York: Academic Press.

Polanyi, K. (1982) The Economy as Instituted Process. In: Granovetter, M. and Swedberg, R. (eds.) The Sociology of Economic Life. Boulder: Westview.

Rasmus, J. (2010) Epic Recession. London: Pluto.

Schaniel, W.C. and Neale, W.C. (1999) Quasi-Commodities in the First and Third Worlds. Journal of Economic Issues, 33(1): 95-115.

Stemmet, F. (1996) The Golden Contradiction: A Marxist Theory of Gold. Aldershot: Ashgate.

Strange, S. (1971a) Sterling and British Policy: A Political Study of a Currency in Decline. London: Oxford University Press.

Strange, S. (1971b) The Politics of International Currencies. World Politics, 23(2): 215-31.

Triffin, R. (1961) Gold and the Dollar Crisis: the Future of Convertibility. New Haven: Yale University Press. 